DOI https://doi.org/10.36059/978-966-397-233-6-7

Олександр Бонь

\title{
Повсякденність у радянських таборах: міфи та реальність
}

\section{Everyday life in soviet camps: myths and reality}

The everyday life in Soviet camps and prisons is a striking narrative of antihuman essence of Soviet terror in Ukraine. We mainly present the memoirs of those who were repressed. This paper analyses the everyday life of repressed humanitarians who were imprisoned in BAMLAH in 1930s.

The scientific base for the research is the memoirs of a Ukrainian museumist $V$. Dubrovskii on his time in BAMLAH as well as the diary of a chief security in this camp I. Chistyakov. We also use archives and published materials of a writer and political prisoner B.Antonenko-Davydovych and Ukrainian artcritics D. Hordeev, $V$. Zummer, S. Taranushenko. The objective of this paper is to explore Soviet and post Soviet myths of everyday life in camps at the end of BAMLAH.

In Soviet and now in Post Soviet historiography as well as in social discussion it is not uncommon to hear that the camp economy was effective. However, after analysing archives and ego-sources we may conclude that it was not effective at all. The main stimuluses for the repressed were the desire to physically survive and be released earlier due to the "active" work and special count of days spent in the camp, this, however, provided wide range of options to the camp administration for psychological, administrative abuse of its powers and the prisoners punishment. The main objective of the soviet system of "the behavior change" was to substitute the socially-political views. The set of influences was used: exhaustive work, unfurnished everyday life, poor nutrition, the quality and quantity of which depended much on extremely high working targets and on social work. Often, socially-psychological transformations had the result, opposite to desirable for the Soviet power.

The situation with an everyday life depended on administration's attitude towards prisoners and their duties. Middle and low level management understood that target underperformance may be considered as sabotage from their side. That is why the practice of additional food for those who were working overtime. Researchers often underestimate the outside support family parcels, friends and colleagues. There were periods and objects where the camp management was forced to care about prisoners. But in this case, the unspecialized force has been employed which was a striking example of an antihuman essence of camps. 
Дослідження репресій проти української гуманітарної інтелігенції в 1920-1930 рр. має потужну історіографію та багато векторів: вивчення біографій репресованих гуманітаріїв, форми та методи репресій, основні категорії репресованих, національне спрямування репресивних заходів радянського режиму та багато інших. Поміж напрямів студіювання державного терору в Україні важливим та особливо переконливим у оприявленні антигуманної сутності більшовицького режиму $\epsilon$ вивчення повсякдення репресованих у таборах і в'язницях. I це переважно спогади тих, хто перебував у цих таборах та передавав персональний досвід життя в часи сталінізму.

Втім, проблема вивчення повсякдення у таборах ГУЛАГу остаточно не вирішена і потребує подальших грунтовних досліджень. Нещодавно у російській серії книг “История сталинизма” опублікували матеріали двох міжнародних наукових конференцій на згадану тематику. Зокрема, у збірнику “История сталинизма: Принудительный труд в СССР. Экономика, политика, память” розглядаються не лише загальні питання економіки ГУЛАГу, а й праця ув'язнених у окремих таборах, адаптація контингенту до існуючих у таборах умов (История сталинизма: Принудительный труд в СССР, 2013). 2013 р. видано збірник матеріалів міжнародної конференції, присвяченої соціальним аспектам репресій. У збірнику автори доповідей розглядають окремі сторони повсякдення терору (История сталинизма: Жизнь в терроре, 2013).

Досить детально вивчено вплив табірної системи на соціально-економічний розвиток окремих районів СРСР. Так, Анатолій Широков присвятив свою монографію ролі Дальбуду (російською - Дальстроя) у розвитку північно-східного регіону СРСР (Колима, Чукотка) (Широков А., 2014). Про повсякдення у таборі коротко говорить Віра Казимир у монографії про одного 3 відомих українських в'язнів БАМЛАГу Василя Дубровського (Казимир В., 2018, с. 172-175). Але загалом в українській та зарубіжній історіографії вивчення повсякдення у радянських таборах ще не викристалізувалось у сталі концепції.

Джерельною базою нашого дослідження стали спогади українського музейника В. Дубровського про перебування в БАМЛАЗі, опублікований щоденник низового командира охорони 
в таборах БАМЛАГу І. Чистякова. А також архівні матеріали особових фондів письменника і політв'язня Б. Антоненка-Давидовича та українського мистецтвознавця Д. Гордеєва, який разом з В. Дубровським та іншими українськими гуманітаріями перебував у таборах на будівництві Байкало-Амурської магістралі та інших шляхів Транссибірської магістралі (Транссибу).

Метою дослідження $є$ вивчення радянських і пострадянських міфів про повсякдення у радянських таборах на прикладі БАМЛАГу.

У радянський час, до розвінчання культу особи Сталіна та початку лібералізації суспільно-політичного життя, про табори мовчали, за влучним висловом Володимира Набокова "наче крові в рот набрали”. Частина сталих уявлень, які склались у суспільній свідомості та історичній науці, почали формуватись ще радянською пропагандою в часи хрущовської “відлиги”. Але складні процеси у суспільстві та історіографії у пострадянський час (зокрема в Російській Федерації) призвели до замовчування, перекручування історичної правди про табірну систему СРСР, зміщення акцентів у оцінці повсякдення у таборах. В українській історіографії дослідження цієї проблеми інтенсифікується в пострадянський час. Ми зосередимося на верифікації цих тверджень-міфів за допомогою матеріалів джерел.

Тривалий час у радянському пропагандистському наративі існував міф про ефективність безкоштовної праці ув'язнених. Але, на нашу думку, примусова праця не може бути ефективною та загалом допустимою. О. Хлевнюк, який яскраво показав зв'язок між економіками, з одного боку, ГУЛАГу та, з другого боку, "не-ГУЛАГу" (так він називав господарство СРСР поза межами каральної системи), вірно вказує, що примусова праця в СРСР - це трагедія, приниження та смерть мільйонів людей. I захоплення внеском табірників до переліку “перемог та тріумфів" сталінського режиму є свідченням моральних деформацій (Хлевнюк О., 2013 , с. 13). Додамо, що ці деформації виявляються як у значної частини суспільства, так і в частини істориків. Особливо потужно цей наратив представлений у Російській Федерації, де політикумом активно пропагується та нав'язується ностальгія за радянськими часами. 
Із зазначеною проблемою тісно пов'язано питання ефективності економіки ГУЛАГу, яке оцінюється дослідниками неоднозначно. Ми виходимо з того, що примусова праця завжди менш ефективна, ніж вільна. Але саме тоталітарна модель була характерна для економіки всього СРСР, яка базувалась не на економічних стимулах, а на адміністративному та часто каральному тиску (зокрема, можна згадати про кримінальну відповідальність за запізнення на роботу). Низьку ефективність праці у таборах, часто поза межами фізичних можливостей людини, підтверджують спогади самих в'язнів сталінських таборів. Для істориків у вивченні цього питання $є$ важливими документальні масиви радянської каральної системи. Але документальні свідчення системи ГУЛАГу чи керівництва каральних органів не $є$ надійними. Оскільки, на нашу думку, зміст таких документів найчастіше визначався тогочасною політичною кон'юнктурою, страхом керівництва табірної системи бути покараними. Ще однією засадничою проблемою $€$ статистика каральної системи, яка була складною, несталою і часто не відображала реального стану справ. Так, у доповідній записці Л. Берії Й. Сталіну та В. Молотову від 27 січня 1945 р. зазначено, що всі табори в роки війни знаходились на повній самоокупності і не отримували жодних дотацій, навпаки, 1944 р. мали накопичення в сумі 1,63 мрд руб. Втім, за доповіддю ГУЛАГу, в березні 1940 р. видатки перевищували прибутки відомства більш ніж на 6,6\% - 488290000 руб. (Белых Н., 2011, с. 172). Вважаємо, що головна проблема полягає у відсутності об'єктивних джерел для оцінки. Адже радянська система обліку не дозволяє виокремити статистично установи ГУЛАГу в довоєнний час - відповідні рішення від 20 серпня 1936 р. не виокремлювали спецконтингенту та ув'язнених у формах звітності підприємств. Це робилися для того, щоб, зіставивши статистику, ніхто не зміг визначити реальної чисельності ув'язнених, засланих - спеціальної робочої сили (Белых Н., 2011, с. 174). Утім, низька ефективність підневільної праці пов'язана, при загальній низькій вартості робочої сили, із значними супутніми витратами в таборах: на охорону, табірну інфраструктуру, управління. Так, витрати на охорону становили 20-25\% від загальних витрат на утримання таборів, а на управління витрачалось ще 10\% коштів (Белых Н., 2011, с. 177). 
Вважаємо, що неефективність табірної праці обумовлювалась низьким рівнем зацікавленості та організаційних умінь адміністрації, недостатнім технологічним рівнем, станом побутових умов і здоров'я ув'язнених. Але, на нашу думку, визначальним для тоталітарного режиму була не економічна ефективність табірної системи, а здатність її реалізувати неринковими методами економічні потреби в тих районах СРСР, де були важкі природні умови і неможливо було забезпечити достатню кількість робочої сили. У таких випадках ефективність відступала на другий план, насамперед сталінське керівництво зважало на стратегічні потреби розвитку північних і далекосхідних регіонів СРСР, майбутнього військового протистояння.

Ще одним відомим радянським міфом $є$ теза про те, що важка праця в таборах і в'язницях перевиховувала “ворогів народу", а культурна робота робила з них радянських людей. Дійсно, одним із головних критеріїв у радянській системі “перековки" була цільова соціальна трансформація - зміна суспільно-політичних поглядів. Тому їй приділяли величезну увагу. Але тут був задіяний набагато ширший комплекс заходів впливу: виснажлива праця, необлаштований побут, погане харчування, якість і кількість якого залежали від виконання надвисоких виробничих норм, культурно-масова робота. Можна стверджувати, що соціально-психологічні трансформації у таборі мали всеохопний, але протилежний від запланованого радянським режимом характер. Про це дуже переконливо писав командир низової ланки позавідомчої охорони (російською - “вневедомственная охрана", звідси скорочене - “вохр”), який служив в охороні БАМЛАГу, Іван Чистяков у своєму щоденнику “Сибирской дальней стороной”. Табірники, бачачи ставлення керівництва, ще негативніше ставилися до більшовицької влади: “Від таких умов мимоволі будуть думки, що всі винні. Табірна адміністрація не піклується про ув'язнених, розтрачує, розтринькує визначене за штатом. У путьармійців (ув'язнені БАМЛАГу, які будували залізничні шляхи - О.Б.) думка, що радянська влада не дає нічого" (Чистяков И., 2014, с. 60). Звісно, що в таких умовах не варто говорити про високу ефективність праці ув'язнених у таборах. 
Нав'язати радянські ідеологічні настанови, за задумом сталінського партійного керівництва, мала т. зв. "культурна" робота. Ув’язнені з об'єкта мали перетворюватися на її суб’єкта. Вони повинні не тільки сприйняти більшовицький варіант комуністичної ідеології, а й відтворювати та продукувати його. Насправді, на нашу думку, “культурна” праця ув’язнених слугувала лише зовнішнім проявом лояльності, проте далеко не завжди була виявом внутрішніх змін. Так, Василь Дубровський у своїх спогадах "2-й Відділ БАМЛАГу ГПУ-НКВД” зауважував, що “культурне” життя і “громадська" робота мало цікавили ув'язнених. Для них значно більший інтерес становили пайка хліба, добавка до їжі, невелика грошова преміальна винагорода за “ударну працю”, стан здоров'я, а найголовніше - закінчення терміну ув’язнення: “пропагандистські видання ГУЛАГу про розквіт культури в кацетах (від “концентраційний табір” - О. Б.) ще більший блеф, ніж вся совєтська пропаганда загалом” (Дубровський В., 1965, с. 65-66). До того ж ця робота була зосереджена переважно у центрах таборів. У БАМЛАЗі, зокрема в його центрі м. Свободному, діяли театр, симфонічний оркестр, газета “Строитель БАМа", кіно, бібліотека, видавались книги і брошури. А у 2 відділі БАМЛАГу на станції Урульга “культура” обмежувалась нечастими кіносеансами, агітбригадами (безпосередньо на будівництві шляхів) та постійною ідеологічною “обробкою” (бесідами) працівників культурно-виховної частини з табірниками, які, нерідко, були значно освіченішими за своїх "вихователів". Штат культурно-виховної частини був численним і повинен був шпигувати за ув'язненими та доносити адміністрації (зокрема 3 секретній частині) про “контрреволюційні” погляди “вихованців” (Дубровський В., 1965, с. 66-67).

Загальнопоширеною практикою в системі ГУЛАГу стало створення театрів, випуск табірних газет, збірок віршів та інших форм культурно-мистецької діяльності ув'язнених. У БАМЛАЗі також була поширена практика, яка свідчить про склад ув'язнених - була значна кількість гуманітарної інтелігенції, яка могла забезпечити функціонування цих інституцій. 1935 р. у м. Свободний була видана збірка віршів ув'язнених про будівництво дороги під назвою “Путьармейцы”. Ілюстрації і заставки 
до таких збірок робив відомий український мистецтвознавець, художник Дмитро Петрович Гордеєв, який потрапив до БАМЛАГу 1935 р. разом з Василем Дубровським, Всеволодом Зуммером та Стефаном Таранушенком та відбув там термін ув'язнення ${ }^{1}$. Виходили також інші збірки.

Утім, всупереч історичній правді та логіці табірного життя, в російській пострадянській історіографії вже сформувався підхід частини істориків, який переконує у реальній “перековці" табірного контингенту та позитивному впливі праці в таборах на їхній моральний стан. Так О. Єланцева, яка є авторкою великої кількості публікацій про будівництво БАМу в 1930-1940 рр. та захистила докторську дисертацію з цієї теми (Еланцева О., 1996), ще 2000 р. в книзі про літературну творчість в'язнів БАМЛАГу не лише не сумнівається у позитивному впливі ГУЛАГу на економіку, а й стверджує, що на психологію табірників позитивно вплинула праця, виконання виробничих завдань і участь у літературній творчості (Еланцева 0., 2000, с. 13, 15-16).

Але переконливим спростуванням таких тверджень $є$ численні свідчення та літературна творчість самих ув'язнених. Ось, наприклад, вірш відомого українського літератора та в'язня сталінських таборів, дисидента Бориса Антоненка-Давидовича. У вірші “Пурга" про табірне життя (припускають, що твір був таємно написаний 1935 р. в БАМлазі) добре видно моральний стан ув'язнених табірників і вплив праці на їхню психологію:

Мете пурга.

Із неба й низу,

Немов поплутані дроти,

Летять кудись каскади снігу,

Та треба йти.

Розвод пробито

I коло вахти жде конвой.

Уже нарядчик, матюкнувшись,

Кричить в барак:

“Арлы, за мной!"

${ }^{1}$ Центральний державний архів-музей літератури і мистецтва України (далі - ЦДАМЛМ України, ф. 208, оп. 2, спр. 17). 
Орли підводяться...

Підбиті крила

I пообсмикані хвости.

Вони давно уже пінгвіни.

А дехто й просто - хробаки.

3 усіх республік, з різних націй -

Це справжній інтернаціонал,

Що легко судячи, немов би насміх,

Його зібрав тут трибунал.

Цей за крадіжку, той за сина,

Що потай за кордон утік,

Цей нишком мріяв про Вкраїну,

А цей і мріяти не встиг...

...Нехай мете і замітає

Тут наші трупи і сліди,

Однаково весна настане,

Розтануть криги і сніги...

1935 р. (ЦДАМЛМ України, ф. 159, оп. 2, спр. 27, арк. 3-5).

Ще одним радянським міфом було твердження про те, що ув'язнені, які працювали у таборах, забезпечувалися всім необхідним і були щасливі “перековуватись”. Поступово у пострадянській історіографії він був заміщений твердженням, що забезпечення у таборі було на дуже низькому рівні, виснажувало і приносило муки табірникам.

У дійсності ситуація у БАМЛАЗі була часто контрастною. Насправді доступ до матеріальних благ був дуже обмеженим. I. Чистяков, описуючи барак однієї з табірних фаланг (виробничих одиниць) БАМЛАГу, яку йому доводилось охороняти, свідчить: “Збіговисько живих істот, а не люди. Чому так? Лахміття. Бруд! Сплять одягнуті, в бушлатах, у валянках, в шапках... Жодного радісного обличчя... День на роботі. У дощ, сніг, бруд. Вночі знову маячня" (Чистяков И., 2014, с. 60).

Але ситуація дуже варіювалась і залежала від ситуації в самому табірному пункті, ставлення адміністрації до в'язнів та до своїх обов'язків, умов праці та часу ув'язнення (хвиль репресій). Також впливали професія і фахова підготовка табірника, 
велика кількість суб'єктивних та часто випадкових факторів. Від сумління табірного начальства нерідко залежало фізичне виживання ув'язнених. Особливо це стосувалося необхідності виконання планів будівництва. Так, на БАМЛАЗі керівництво середньої і низової ланки розуміло, що невиконання плану може розцінюватися як саботаж з їхнього боку та загрожувати ув'язненням. Тому змушене було робити все, щоб забезпечити виконання планів і строків будівництва. Іван Чистяков зафіксував у своєму щоденнику випадок, коли він сам повинен був умовляти жіночу бригаду, яка відмовлялась від роботи у небезпечному котловані під час будівництва мосту. I лише завдяки психологічному впливу вдалося їх переконати (Чистяков И., 2014, с. 57).

Але були також й інші методи. Їх відображають документи 3 архіву українського мистецтвознавця Дмитра Гордеєва. Так, існувала практика посиленого харчування для фаланг і бригад, які працювали понадурочно на місцях “проривів" (відставання від плану виконання робіт) та “ударниках”, які застосовували для виконання і перевиконання плану до радянських свят. Про участь у такому “ударнику” писав Д. Гордеєв 23 листопада 1934 р. у спеціальній замітці в газеті “Строитель БАМАа”: про ударну працю чоловіків і жінок, дощ, який не зламав ентузіазму табірників, боротьбу за "червону" тачку, якою нагороджували тих, хто перевиконував норму. А особливо вражаюче виглядав опис харчування працівників: були привезені просто-таки на будівництво колій холодні закуски, солодкі страви і фрукти ${ }^{1}$. Але куштувати ці наїдки ув'язнені не мали ані часу, ані сил.

В. Дубровський згадує також про те, що в 1935-1936 pp. 3 метою виконання плану будівництва та підвищення продуктивності праці для “стаханівців” було організовано спеціальні їдальні з можливістю придбати за невеликі кошти калорійні страви (Дубровський В., 1965, с. 31).

Часто дослідники недооцінюють допомогу ззовні - посилки родин, допомога знайомих, колег та ін. Д. Гордеєв отримував у БАМЛАЗі посилки від рідні, котрі допомагали виживати.

${ }^{1}$ ЦДАМЛМ України, ф. 208, оп. 2, спр. 243, арк. 23 зв. 
Це пояснюється лояльністю начальства у період необхідності виконання плану будівництва, коли режим у таборі не був таким убивчим. У зимову пору року ключовим фактором виживання ставав одяг і взуття. Табірне забезпечення було поганим, тому Дмитро Гордеєв у листі до сестри Христини Гордеєвої у Тифліс в жовтні 1934 р. малював фасон теплих штанів, які вона мала пошити та вислати йому. Ще раніше він отримав від Христини посилкою сало, лимони, інші продукти, светр, жилети та пару теплих панчох ${ }^{1}$.

Засадничим радянським міфом було твердження, що табори існували для перевиховання політичних противників режиму. Насправді вони були важливим засобом вирішення економічних завдань. Особливо в тих районах, де економічними ринковими методами радянська неринкова система діяти не могла. Особливо точно про це говорить О. Хлевнюк, коли зауважує зв'язок економіки ГУЛАГу і не-ГУЛАГУ: репресії, викликані політичними причинами, вимагали використання праці величезної кількості ув'язнених, а розширення економіки ГУЛАГУ вимагало все більшої кількості репресованих (Хлевнюк 0., 2013, с. 13).

У системі ГУЛАГу були створені окремі головні управління таборів у гірничо-металургійній, лісовій галузях, у сферах залізничного, промислового, гідробудівництва, у процесі побудови шосейних доріг, а також інші галузеві управління. Вони складали значний відсоток у товарній продукції цих галузей, найбільше - у лісовій, деревообробній, швейній, гірничо-металургійній. Станом на 1940 р. промисловість ГУЛАГу виробляла на 1,1457 млрд руб. та створювала в процесі будівництва цінності кошторисною вартістю 1,8804 млрд руб. (Политические репресии на Дальнем востоке. 1997, с. 258-262).

Ще одним поширеним радянським міфом було те, що після табору ув'язнені могли звільнитися та почати “нове життя”. Насправді ж, згідно з тогочасним законодавством, вони часто залишались табірною адміністрацією для поселення в тих самих віддалених районах, де відбували покарання, або вільнонайманими (в'язні називали їх “вольняшками”) в таборах.

\footnotetext{
${ }^{1}$ ЦДАМЛМ України, ф. 208, оп. 1, спр. 706, арк. 7.
} 
За незгоду залишатися на будівництві, де катастрофічно бракувало кваліфікованих працівників, ув'язненим погрожували або знімали пільговий облік ударних днів (“зачёты”), який дозволяв звільнитися раніше строку (История сталинского Гулага, 2004, с. 126-132). Так, Василь Дубровський згадує про такий випадок з топографом-геодезистом Миколою Аксьоновим, який мав пільгові заліки за Біломорканал і БАМ, але коли його строк підійшов, то його пільги було скасовано, і він мав ще допрацьовувати на БАМЛАЗі 3,5 роки (Дубровський В., 1965, с. 58). Але сам В. Дубровський, як і згадані його українські колеги-професори Д. Гордеєв, В. Зуммер і С. Таранушенко, змогли скористатися пільговими заліками днів за ударну працю та повернутися з таборів раніше. Тільки В. Зуммер як вільнонайманий був змушений деякий час пропрацювати на БАМі.

Поряд з радянськими міфами з'явились і пострадянські міфи, які спричинені тим, що розпочали вивчення проблем табірного життя літератори і публіцисти, які не використовували всієї повноти документальних свідчень сталінського періоду і грунтувались, переважно, на спогадах. Так сформувалось твердження, що в табірних умовах радянське “перевиховання" скоріше нагадувало вбивство. Втім, дуже складною є наукова проблема кількості ув'язнених та їх смертності. У 1990 рр. історики некритично ставилися до статистики каральних органів. Зокрема, смертність у Дальстрої, Севвостлазі (Колима) становила 3-5\% ув'язнених (Политические репресии на Дальнем Востоке, 1997, с. 274). Це була велика кількість ув'язнених, хоча смертність не носила тотального характеру. Але був значний контингент “слабосильних” ув'язнених, інвалідизованих.

Якщо спиратися на норми статистики ГУЛАГу, то можуть бути значні викривлення. Після відкриття архівів не припинилася полеміка щодо кількісних характеристик ГУЛАГу. I справа не лише у прагненні частини авторів применшити чи перебільшити масштаби терору у сталінські часи, а в складності, заплутаності та помилках табірної статистики. Вирішальну роль грає те, що статистика ГУЛАГу не могла спиратися на правдивий первинний статистичний облік у самих таборах. Тому вона часто викривлена, переповнена помилками неграмотного табірного 
керівництва (навіть у сумах цифр у таблицях звітності за контингентом ув'язнених). Через помилки у звітності (наприклад, плутали річну і середньомісячну смертність у таборах) робились хибні висновки про чисельність ув'язнених та їхню смертність. Так само критично потрібно ставитися до тогочасних методик підрахунку кількості контингенту таборів, які свідомо маніпулювали і приховували істинний стан речей (Иванова Г., 2006, с. 51-53).

У секретній довідці начальника ГУЛАГу Наседкіна вказано, що 1942 р. померло 352560 чол., або 2,08 \%, 1943 р. 267807 чол., або 1,87 \%. Це дозволяє зробити висновок, що 1942 р. в ГУЛАЗі було близько 17 млн ув'язнених, а 1943 р. 14,3 млн. Саме так інтерпретує ці дані російський дослідник А. В. Антонов-Овсієнко. Проте в довідці вказано кількість померлих за рік і одночасно середньомісячний процент смертності. У документі вказано цифри за новою методикою, уведеною 1943 р. До того (в 1931-1942 рр.) рівень смертності розраховувався діленням числа померлих за рік на середньорічну чисельність ув'язнених. А з 1943 р. число померлих за рік представлялось як сума померлих за кожний місяць, яка ділилась на суму середньомісячних показників чисельності ув'язнених. За старою методикою: у 1942 р. потрібно 352560 поділити на середньорічну чисельність ув'язнених (1412 500 осіб) і помножити на 100-24,96\%. Нова методика: 352560 треба поділити на суму середньомісячних показників чисельності ув'язнених в 1942 р. (16 950000 чол.) та помножити на 100. Маємо 2,08\%, що в 12 разів менше (Иванова Г., 2006, с. 52).

Оскільки статистика неповна та викривлена, а іноді й штучно сфальсифікована табірним керівництвом, вона вимагає критичного ставлення до джерел. Найбільший контингент ув'язнених, через важкі кліматичні умови та необхідність виконання важких робіт на великій території, був на Колимі: 1940 р. - 246422 , 1941 р. - 210 676, 1942 р. - 262421 (Политические репрессии на Дальнем Востоке, 1997, с. 258-262). За даними Г. Іванової станом на 1 липня 1940 р. на Колимі була дещо менша кількість табірників - 190309 (Иванова Г., 2006, с. 58). 
0. Хлевнюк вказує, що у системі ГУЛАГу станом на 1 січня 1953 р. у таборах і колоніях перебувало 2,5 млн осіб, а на спецпоселеннях та засланні - 2,8 млн осіб. Отже, це становило $3 \%$ населення та ще більшу частку дорослого населення країни. Постійно зближувались норми (яких, втім, не дотримувалися) у забезпеченні ув'язнених та рядових жителів СРСР по хлібу, картоплі. У середньому споживалось 500 г хліба (у таборах норма - 700 гр) (Хлевнюк 0., 2013, с. 8-10).

Загалом потрібно визнати правильність твердження 0. Хлевнюка, який, слідом за німецькими дослідниками, вказував, що рабів у Давній Греції та Римі від ранньої смерті оберігали, оскільки від них залежало благополуччя рабовласника. У керівництва таборів такої залежності не було (Хлевнюк, 0., 2013, с. 13-14), однак були певні періоди і об’єкти будівництва, які змушували табірне керівництво піклуватися про контингент ув'язнених. Втім, використання їх не у відповідності 3 кваліфікацією (згадаємо названих вище чотирьох українських гуманітаріїв-професорів) та за пониженим розрядом чітко вказує на антигуманну сутність системи таборів. Постійний притік ув'язнених послабляв зацікавленість у збереженні робочої сили.

Отже, можемо зробити висновок, що ставлення до питання повсякдення, зокрема підневільної праці у радянських таборах, не $€$ питанням суспільної чи наукової кон'юнктури, а є сутнісним питанням. Інакше формування у суспільстві розуміння допустимості примусової праці для досягнення “високих" державних цілей може призвести до повторення авторитарного чи тоталітарного режиму, як це сталось у Російській Федерації.

Ефективність табірної економіки, а, значить, праці ув'язнених, була низькою, оскільки не мала економічних стимулів. У неринковій радянській економіці економіка ГУЛАГУ теж функціонувала як неринкова. Головними стимулами репресованих були бажання фізично вижити і раніше звільнитися з таборів за рахунок “ударної” праці та пільгового зарахування днів. Це відкривало адміністрації таборів великі можливості для психологічного і адміністративного впливу та використання примусової праці для покарання й “перековки” ув’язнених. 


\section{Література}

Белых, Н. Ю. 2011. Экономика ГУЛАГа как система подневольного труда (на материалах Вятлага 1938-1953 гг.). Москва : Российская политическая энциклопедия (РОССПЭН): Фонд “Президентский центр Б. Н. Ельцина”. (История сталинизма).

Дубровський, В. 1965. 2-й Відділ БАМЛАГу ГПУ-НКВД. Нью-Йорк : Наша Батьківщина.

Еланцева, О. П. 2000. БАМЛАГ в контексте истории и литературы [30-е гг. XX в.] : Из фондов дальневост. б-к. Владивосток : Изд-во Дальневост. ун-та.

Еланцева, О. П. 1996. Строительство Байкало-Амурской железнодорожной магистрали (30-е - начало 50-х годов): исторический опыт : автореф. дисс. ... д-ра ист. наук.

Иванова, Г. М. 2006. История ГУЛАГа, 1918-1958: социально-экономический и политико-правовой аспекты. Москва : Наука.

История сталинизма: жизнь в терроре. Социальные аспекты репрессий : материалы Международной научной конференции, Санкт-Петербург, 18-20 октября 2012 г. 2013. Москва : Издательство Фонда “Президентский центр Б. Н. Ельцина” : РОССПЭН.

История сталинизма: Принудительный труд в СССР. Экономика, политика, память : материалы международной научной конференции. Москва, 28-29 октября 2011 г. 2013. М. : Российская политическая энциклопедия (РОССПЭН); Фонд “Президентский центр Б. Н. Ельцина".

История сталинского Гулага. Конец 1920-х - первая половина 1950-х годов : Собрание документов в 7 т. Т. 3. Экономика Гулага. 2004. М. : “Российская политическая энциклопедия” (РОССПЭН).

Казимір, В. А. 2018. “Правда і добра воля переможуть”. Життя та діяльність Василя Дубровського в Україні (1897-1943) : монографія. Харків, Чернігів : Видавець Олександр Савчук.

Политические репресии на Дальнем востоке СССР в 1920-1950-е годы : материалы первой Дальневосточной научно-практической конференции. 1997. Владивосток : Изд-во Дальневост. ун-та.

Хлевнюк, 0. 2013. Зоны советской экономики. Разделение и взаимодействие. История сталинизма. Принудительный труд в СССР. Экономика, политика, память : материалы международной научной конференции. Москва, 28-29 октября 2011 г. Москва : Российская политическая энциклопедия (РОССПЭН); Фонд “Президентский центр Б. Н. Ельцина”, 8-18. 
Центральний державний архів-музей літератури і мистецтва України (ЦДАМЛМ України), ф. 159, оп. 2, спр. 27, 7 арк.

ЦДАМЛМ Україн и, ф. 208, оп. 1, спр. 706, 28 арк.

ЦДАМЛМ Україн и, ф. 208, оп. 2, спр. 17, 20 арк.

ЦДАМЛМ України, ф. 208, оп. 2, спр. 243, 32 арк.

Чистяков, И. 2014. “Сибирской дальней стороной. Дневник охранника БАМа, 1935-1936". Москва : ACT: CORPUS.

Широков, А.И. 2014. Дальстрой в социально-экономическом развитии Северо-Востока СССР (1930-1950-е гг.). Москва : Политическая энциклопедия. 